\title{
Choosing a Reclamation Seed Mix to Maintain Rangelands During Energy Development in the Bakken
}

\section{A proper revegetation seed mix keeps land in livestock production and minimizes weed invasions}

\author{
By Erin K. Espeland
}

\section{On the Ground}

- Pipelines across the eastern Montana-western North Dakota portion of the northern Great Plains are proliferating due to continuing oil and gas development.

- Pipelines are linear disturbances reclaimed after construction, and they impact a large number of livestock producers.

- While livestock are usually removed from pastures during the construction phase, proper reclamation and revegetation paired with informed grazing management may return pastures to use quickly and profitably.

- Research is needed to determine how the simultaneous seeding of an annual cover crop with desired perennial grasses can enhance livestock production while ensuring the success of perennial grass forage species.

Keywords: grazing, cover crop, reclamation, plant competition, facilitation.

Rangelands 36(1):25-28

doi: 10.2111/RANGELANDS-D-13-00056.1

(C) 2014 The Society for Range Management

\footnotetext{
I
} $\mathrm{n}$ the dry prairie landscape of western North Dakota and eastern Montana, an area previously known only for its low population density and the ability to get away from it all, few vistas remain uninterrupted. Access roads, pumping stations, and pipelines can be seen in every direction. For the livestock producer, pipelines can be a special problem that limits property access, introduces or increases weed problems, and reduces profitability by taking pastures out of production. With many hundreds of miles of pipelines in construction every year, most producers in the region have to deal somehow with this disturbance to their pastures. Through wise planning and the cooperation of energy companies that usually hold permanent easements over pipeline right of ways, landowners can limit obstacles to livestock production. The seed mix chosen for revegetation of pipelines may provide an opportunity for increased production, and there are many areas where research has the potential to profoundly affect the economics of rangeland reclamation. In this article, I outline my opinions and others' collected from conversations regarding landowners' concerns surrounding the process of energy development on their land, summarize the state of the science for reclamation seedings, and show how I think the science can be applied to mitigate some of the damage that the disturbance of energy development brings to rangelands.

\section{The Landowner Point of View}

Most landholders that have had the opportunity to negotiate an easement with energy companies hold some regretsthings they wish they had done better. Enough regret has accumulated that county conservation districts, extension offices, and Natural Resources Conservation Service (NRCS) districts have put together workshops for landowners about to take the plunge into easement negotiation. Landownerrights groups are beginning to form and share information about the types of agreements and concessions to protect producers' current land uses, their future plans, and their way 
of life. This information sharing should help first-time negotiators avoid some of the regrets that their predecessors have about what they should have done and the concessions they could have asked for in negotiating the pipeline easement.

The company landman shows up at your door with a twopage contract that he says all your neighbors have signed. You don't really have much of a choice-eminent domain applies and a pipeline is coming through your property. What you don't know is that there are many concessions that are easily added to that two-page contract that will ultimately affect your future land use and profitability. If you put yourself in the company's shoes, why offer to sign a more complicated contract than you have to? But, with a little pressing, you can get a commitment to protect your land from much of the accessory hazards of pipeline construction and reclamation. Examples of concessions can be found in the pipeline reclamation checklist (referenced in the Box).

Ask anyone who has had energy development on their property and they can give you a litany of accessory hazards: dust, a lot of people driving around your once-peaceful property, gates left open, cattle scared, new weeds, and erosion, to name a few. Some of these are temporary inconveniences and others can leave a long-term legacy that negatively impacts rangeland productivity. Long-term rangeland productivity is what producers want, and that productivity can be protected as long as end use is considered throughout the easement negotiation, construction, and reclamation process. As Pete Stahl of the Wyoming Reclamation and Restoration Center says, "Reclamation starts with construction planning." The Box shows some of the resources available to land owners contemplating an easement agreement.

Construction planning includes a vision for the future of the property. Factors that will impact the profitability of the property include weeds and their management as well as a grazing plan that incorporates expectations for new waterlines, fencing, and other types of property development. Communication that is specific regarding tolerance towards new weed invasions, appropriate management of weedy patches, livestock densities, water access, and forage utilization will allow landowners and leaseholders to work together to maintain rangelands. A weed management plan can be part of the easement agreement, and plans for future developments (such as fences and waterlines) should also be included in the agreement.

\section{Planning for Profits: Revegetation for Stable Production and Weed Minimization}

Pipeline construction can be planned to avoid sensitive areas such as those ecological site types that may be difficult to revegetate, or areas that have difficult topography. Post-construction, pipeline reclamation in the eastern Montana-western North Dakota (MonDak) region begins with restoring landscape contours using subsoils first, then placing topsoil that was separated during the construction process on top. The soils are packed to prevent erosion and blowouts and to provide a seedbed for planting. The revegetation seed mix is
Information Resources for Livestock Producers in Managing Disturbance and Reclamation

North Dakota noxious weed lists by state, county, plus city and county weed coordinator contact information

http://www.nd.gov/ndda/program/noxious-weeds

Identification of Montana's noxious weeds http://www.mtweed.org/weed-identification/

Management and ecology of invasive plant species http://www.mt.nrcs.usda.gov/technical/ecs/invasive/ management/

Planting methods, species to plant, seedbed preparation, post-reclamation weed control http://www.mt.nrcs.usda.gov/technical/ecs/plants/ technotes

\section{Planting procedures, baseline data collection, soils management, wildlife considerations, and monitor- ing techniques \\ http://www.uwyo.edu/wrrc/bulletins.html}

Pipeline reclamation checklist (from Sidney, Montana ARS website-www.ars.usda.gov/npa/nparl) http://www.ars.usda.gov/SP2UserFiles/Place/54360500/ Pipeline/Landowners_Tips.pdf

Useful internet search terms

"pipeline conditions of approval"

"pipeline stipulations"

"university extension oil and gas lease"

critical for weed exclusion and for a speedy return to livestock production.

What goes into a revegetation seed mix? Seed mixes have been constructed for some common ecological site types in the MonDak region by the Bridger Plant Materials Center (Susan Winslow, USDA-NRCS, personal communication, March 2013). Conservative practice is to only include species that are naturally found at the site prior to construction. Seed mixes should be reviewed carefully by landowners-federal agencies such as the Bureau of Land Management (BLM) still use crested wheatgrass in revegetation mixes for some site types, but many landowners wish to avoid the introduction of this sometimes-invasive exotic species. Buying native seed is expensive, but, as the scientific literature shows, a diverse native seed mix may pay off in the long run.

Diversity can be measured in two ways: 1) the number of species, or 2) the number of functional groups. Functional groups may be defined by cool- vs. warm- season grasses, bunchgrasses vs. rhizomatous grasses, annual forbs vs. perennial forbs, and forbs vs. grasses. Functional groups indicate the timing of resource use by the plants as well as the space they take up. When there is more time and space taken up 
by desired species, there is less opportunity for weed encroachment. This has been demonstrated experimentally in the southeastern corner of North Dakota ${ }^{1}$ and has also been shown in more arid systems. ${ }^{2}$ In addition, more diversity in the planting mix means that forage production will be more stable year to year. Different species have different optimal climates, so diversifying the species mix increases the chances that in any particular year at least one species in the mix will do well. Again, this relationship between plant diversity and stability in above-ground production has been demonstrated in multiple ecological site types. ${ }^{3}$ In addition, more species diversity in an established plant community extends the period of growth of quality forage by incorporating species with different growth seasonalities. ${ }^{4}$

An economic tradeoff exists between the high cost of a diverse seed mix and the costs of subsequent weed control activities and risks of low forage production as the years go by. Native seed can be very difficult to find, so purchasing seed well before (even years before) it is needed can ensure access to a variety of species. Years with low fire rates across the western United States are an excellent time to purchase native seeds because federal agencies such as the BLM and Forest Service can exhaust seed supplies in years where many millions of acres of rangeland require reseeding due to large and numerous fires. ${ }^{5}$

\section{Adding New Species to the Land: Simultaneous Cover Crops}

It is a common practice to include annual grass species as a simultaneous cover crop (annuals seeded at the same time as perennials) in revegetation mixes. These species are often not naturally found at the site, but they provide an instant greenup within the revegetation area and may increase the success of seeded perennial species. This is counterintuitive: we think of plants as competing with one another and an annual grass that puts on a lot of growth in the first year may shade out establishing perennial grass seedlings that grow much more slowly. However, in experiments I conducted within a MonDak water pipeline reclamation, ${ }^{6}$ I showed that perennial grass growth and establishment is not reduced by annuals in field conditions. I observed competition in only one instance: in a well-watered greenhouse experiment using farm, not rangeland, soils. There was some evidence for annual grasses helping perennial grass establishment and growth in reclamations. This is supported by research showing that, in stressful environments, having another plant as a neighbor can increase water infiltration and nutrient availability.

\section{Simultaneous Cover Crops and Grazing Within Reclaimed Areas}

Although planting annual grasses as a simultaneous cover crop can increase surface soil stability and possibly even improve the establishment of desired perennial species, in my opinion annual grasses also have the potential to become weedy in the MonDak region. Some climate change models predict in- creased habitat suitability in the region for weedy annuals, ${ }^{8}$ and annual grasses such as downy brome (or, cheatgrass, Bromus tectorum L.) are already weedy in some areas. ${ }^{9}$ Some practitioners use sterile annual grasses for their simultaneous cover crop, but sterile species can still produce some seed ${ }^{10}$ and when thousands of miles of pipeline are seeded, risk of invasion is increased. In my experiments on the water pipeline, I noticed that cattle ate almost every single annual grass plant (oats and millet in this case), preventing them from setting seed. These large annual grass individuals also prevented the slender leaves of establishing perennials from being grazed, as the annuals were presumably more attractive forage. Very few annual grasses persisted in the reclamation after the first year.

Reclaimed seedbeds are stressful sites: bare soils increase runoff, soil horizons have been disturbed, and beneficial soil microorganisms may be at low levels. Recommended seeding rates in pipeline reclamations are twice that of normal restoration seeding ${ }^{11}$ because of the stressful environment. Standard practice for revegetation on bare soils is to exclude grazing for two years in order to allow seedlings to establish. However, during my water pipeline research, grazing was not interrupted during the construction or reclamation phases. In fact, grazing may have been essential to prevent the spread of annual grasses beyond the revegetated area, and the presence of cattle may have increased seed-soil contact to create better conditions for germination. ${ }^{12}$ To my knowledge, no scientific research has been performed on the benefits of immediate grazing of an annual simultaneous cover crop. The current practice of taking pastures out of production for two years to facilitate seeding success represents a significant economic loss to livestock producers that may be unwarranted under some conditions.

The years I conducted my experiments in the MonDak water pipeline were some of the wettest in recent history. This meant that germination was good and the perennial grasses grew. In the case of low-rainfall years and little germination of perennial grasses, annual cover crops may need to be resown in order to provide the protective benefit to perennials under grazing. Again, I think we need research to confirm that annual grasses can protect emerging perennial grasses within grazed pasture reclamations.

\section{The Potential for Increased Livestock Production}

Livestock do not use pastures uniformly. Areas experience different grazing pressure as cows regulate their temperature (seek shade, ${ }^{13}$ gather around water sources ${ }^{14}$ and choose desirable plant species ${ }^{15}$ ). Reclaimed pipelines may attract high livestock use because they are easy to walk on and have green forage with little plant litter. Not only can this affect revegetation success, but it will also affect the utilization of the undisturbed portion of the pasture and potentially change plant species composition. It is possible that pastures with reclaimed pipelines may be able to support increased numbers of animal units because livestock may prefer the reclamation and therefore utilization of the surrounding pasture may be lighter compared to prerec- 
lamation conditions. Alternatively, there is a diversity of personalities within cattle herds, and management of personality types may increase the number of animal units a pasture can support by increasing the uniformity of pasture utilization over the entire herd. ${ }^{16}$ There are many opportunities for additional research to improve information regarding the use of the disturbance of pipeline construction to increase agricultural productivity, at least in the short-term.

\section{Moving Forward to Enhance Livestock Production as Pressures on Rangeland Increase}

Increasing energy development in the MonDak region represents a vast and unexploited natural experiment on fragmentation, reclamation, and livestock production. Pipelines in particular are an important type of disturbance because they are linear and have a great deal of edge (unlike many other types of reclamation areas), and because they impact thousands of miles and many livestock producers. As much as some people might like it to, many agree that energy development in this region is not going away anytime soon. We can use this disturbance as an opportunity to understand how to increase the long-term success of revegetation when paired with practices that also enhance livestock production.

\section{Acknowledgments}

I would like to thank Beth Redlin, Wayne Berry, Vernon Bleich, Jack Norland, and the researchers at the Wyoming Reclamation Research Center (particularly Brenda Schladweiler, Pete Stahl, and Calvin Strom) for introducing me to this problem and beginning my education. Thanks to Richard Waterman for references on pasture use and to John Gaskin, Jon Perisian, Lance Vermeire, and an anonymous reviewer for comments on the manuscript.

\section{References}

1. Biondini, M. E., J. E. Norland, and C. E. Grygiel. 2011. Plant richness-biomass relationships in restored northern Great Plains grasslands (USA). International Journal of Ecology doi:10.1155/2011/856869.

2. Maron,J., ANd M. Marler. 2007. Native plant diversity resists invasion at both low and high resource levels. Ecology 88:2651-2661.

3. Srivastava, D. S., and M. Vellend. 2005. Biodiversity-ecosystem function research: is it relevant to conservation? Annual Review of Ecology, Evolution, and Systematics 36:267-294.

4. Vallentine, J. F. 1990. Range Management. San Diego, CA, USA: Academic Press. 533 p.
5. Associated Press. 29 October 2012. Native seed shortage hampers wildfire recovery. Reno Gazette Journal.

6. Espeland, E. K., and L. B. Perkins. 2013. Annual cover crops do not compete with perennial grasses on a disturbed restoration soil in the northern Great Plains USA. Ecological Restoration 31:69-78.

7. Maestre, F. T., S. Bautista, and J. Bellot. 2001. Potential for using facilitation by grasses to establish shrubs on a semiarid degraded steppe. Ecological Applications 11:1641-1655.

8. Morgan, J. A., J. D. Derner, D. G. Milchunas, and E. PenDALL. 2008. Management implications of global change for Great Plains rangelands. Rangelands 30(3):18-22.

9. Menalled, F., J. Mangold, and E. Davis. 2008. Cheatgrass: identification, biology and integrated management. Bozeman, MT, USA: Montana State University Publication 500-1008SA. $4 \mathrm{p}$.

10. Morris, C., And E. W. Schupp, 2009. Comparison of emergence speed and sterility in two sterile annual hybrid cereal grasses developed for use in restoration. Restoration Ecology $17: 678-684$.

11. NRCS. 2005. Natural Resources Conservation Service Conservation Practice Standard Critical Area Planting Code 342. Available at: http://efotg.sc.egov.usda.gov/references/public/ NM/342.pdf. Accessed 2 July 2013.

12. Mullen, B. F. 1994. Practical pasture establishment under plantation crops. In: B. F. Mullen and H. M. Shelton [EDs.]. Integration of ruminants into plantation systems in Southeast Asia. Canberra, ACT, Australia: ACIAR Proceedings No 64. p. 28-31.

13. Kerren, E. N., and B. E. Olson. 2006. Thermal balance of cattle grazing on winter range: model application. Journal of Animal Science 84:1238-1247.

14. Ganskopp, D. 2001. Manipulating cattle distribution with salt and water in large arid-land pastures: a GPS/GIS assessment. Applied Animal Behaviour Science 73:251-262.

15. Senft, R. L., R. L. R. Rittenhouse, and R. G. Woodmansee. 1985. Factors influencing patterns of cattle behavior on shortgrass steppe. Journal of Range Management 38:82-87.

16. BAiley, D. W. 2004. Forage and pastures symposium-forage strategies for arid climates: management strategies for optimal grazing distribution and use of arid rangelands. Journal of Animal Science 82:E147-E153.

Author is Research Ecologist, USDA-ARS Pest Management Research Unit, Sidney MT 59270, USA, Erin.Espeland@ars. usda.gov. 